\title{
FAKTOR-FAKTOR YANG MEMPENGARUHI KINERJA MANAJERIAL SATUAN KERJA PERANGKAT DAERAH (SKPD) PEMERINTAH KOTA MAGELANG
}

\author{
Martinus Budiantara \\ Fakultas Ekonomi, Universitas Mercu Buana Yogyakarta \\ krissnak@gmail.com \\ Nugraeni \\ Fakultas Ekonomi, Universitas Mercu Buana Yogyakarta \\ nda_eni@yahoo.com
}

\begin{abstract}
The purpose of this study was to test empirically and analyzes the factors that influence the performance of managerial work units (SKPD) Magelang city government. These factors include participation in budgeting, budget goal clarity and decentralized structure. Management accountable local government, can not be separated from local government budgets. In preparing the budget, the government has implemented the participation of each unit of work in preparing the budget. The key to effective performance is the participation of subordinate plays an important role in achieving these objectives. Budget goal clarity illustrate the scope of the budget stated clearly and specifically, and understood by those responsible for their achievement. The existence of a clear budget targets will allow employees to draw up budgetary targets. Budget goal clarity will help employees to achieve the expected performance, which by knowing the budget target performance levels can be achieved. The more decentralized structure of government organizations in the region, the higher the head SKPD performance in running the financial management area. This led to research in the field of local government budgets, to be relevant and important.

The study population was 26 Unit (SKPD) in the city of Magelang with a total sample of 75 people consisting of employees of accounting and budgeting. Data was collected by questionnaire and analyzed using multiple regression analysis.

The result is that participation in budgeting, budget goal clarity and structure of decentralization affect the improvement of managerial performance SKPD either partially or simultaneously.
\end{abstract}

Keyword: participation in budgeting, budget goal clarity, decentralized structure, managerial performance

\section{PENDAHULUAN}

Pelayanan publik menurut Miftah Thoha (1994) dalam Abdulloh (2006) merupakan suatu kegiatan yang harus mendahulukan kepentingan umum, mempermudah urusan publik, mempersingkat waktu pelayanan dan memberikan kepuasan kepada publik. Hal senada juga dinyatakan oleh Has Munir (1995) dalam Abdulloh (2006) yang mengemukakan bahwa pelayanan publik adalah kegiatan yang dilakukan oleh seseorang atau sekelompok orang dengan landasan fungsi material melalui sistem, prosedur dan metode tertentu dalam usaha untuk memenuhi kebutuhan orang lain sesuai haknya. Peningkatan pelayanan kepada publik oleh instansi pemerintah sangat membutuhkan peningkatan kinerja karyawannya secara menyeluruh.

Ada beberapa faktor yang diduga penyebab kinerja pemerintah daerah rendah diantaranya karena sistem pengelolaan keuangan daerah yang masih lemah, dimulai dalam proses perencanaan dan penganggaran APBD, 
pelaksanaan/penatausahaan

APBD, pertanggungjawaban yang berupa pelaporan hasil pelaksanaan APBD dan pengawasan. Dalam proses penganggaran, pemerintah daerah selalu mengalami keterlambatan di dalam pengesahan perda APBD. Keterlambatan ini menyebabkan banyak program dan kegiatan yang tidak dapat dilaksanakan untuk tahun anggaran berjalan sehingga terjadi keterlambatan pembangunan daerah tersebut.

Hampir di semua aspek pengelolaan keuangan daerah, SKPD memiliki kelemahan sehingga dapat dikatakan kinerja SKPD masih rendah. Di satu sisi, semakin meningkat tekanan dari masyarakat agar pemerintah daerah meningkatkan kinerja dan akuntabilitas demi terwujudnya good governance menyebabkan pemerintah daerah harus membenahi diri untuk merespon perubahan yang diinginkan oleh masyarakat sebagai stakeholder. SKPD diharapkan memiliki kinerja yang baik yaitu dengan memperbaiki kualitas pelayanan kepada masyarakat.

Pengelolaan pemerintah daerah yang berakuntabilitas, tidak bisa lepas dari anggaran pemerintah daerah. Mardiasmo (2009) mengatakan wujud dari penyelenggaraan otonomi daerah adalah pemanfaatan sumber daya yang dilakukan secara ekonomis, efisien, efektif, adil dan merata untuk mencapai akuntabilitas publik. Anggaran diperlukan dalam pengelolaan sumber daya tersebut dengan baik untuk mencapai kinerja yang diharapkan oleh masyarakat dan untuk menciptakan akuntabilitas terhadap masyarakat.

Secara teknis, perkiraan keadaan yang akan terjadi di masa mendatang menjadi pertimbangan penting dalam penyusunan anggaran. Keadaan internal yang berada di bawah kendali semestinya bisa diakomodasikan dengan baik. Persoalan yang muncul adalah perubahanperubahan eksternal yang berada di luar kendali sehingga sulit diperkirakan. Kemampuan melihat jauh ke depan semacam ini yang akan menentukan ketepatan anggaran dengan realisasinya. Selisih antara anggaran dengan realisasinya menjadi indikator "keberhasila penyusunan anggaran. Sebagai konsekuensinya, penyusun cenderung selalu bersikap mencari aman dengan menetapkan anggaran pada angka yang relatif rendah dengan harapan agar dapat dengan mudah dicapai realisasinya. Kesalahan memprediksi akan mengacaukan rencana yang telah disusun dan berdampak terhadap penilaian kinerjanya. Anggaran pada sektor publik meliputi aspek perencanaan, aspek pengendalian, dan aspek akuntabilitas publik. Anggaran sebagai perencanaan yang dimaksud adalah anggaran merupakan rencana kegiatan yang terjadi dari sejumlah target yang akan dicapai oleh para pimpinan dari suatu instansi dalam melaksanakan kegiatan tertentu pada masa yang akan datang. Anggaran tidak saja sebagai alat perencanaan keuangan dalam sistem pengendalian manajemen, tetapi juga sebagai alat pengendalian, koordinasi, komunikasi, evaluasi kinerja dan motivasi (Halim dan Husien, 2000) yang menyebabkan penelitian di bidang anggaran pada pemerintah daerah, menjadi relevan dan penting.

Kenis (1979) mengatakan terdapat 2 (dua) karakteristik sistem penganggaran, yaitu partisipasi dalam penyusunan anggaran dan kejelasan sasaran anggaran. Dalam penyusunan APBD, pemerintah telah menerapkan partisipasi setiap satuan kerja dalam penyusunan anggaran. Kejelasan sasaran anggaran menggambarkan lingkup anggaran yang dinyatakan secara jelas dan spesifik, dan dimengerti oleh pihak yang bertanggungjawab terhadap pencapaiannya. Adanya sasaran anggaran yang jelas akan memudahkan pegawai untuk menyusun target-target anggaran. Selanjutnya, target-target anggaran yang disusun akan sesuai dengan sasaran yang ingin dicapai organisasi. 
Faktor berikutnya yang mempengaruhi kinerja adalah struktur desentarliasi. Struktur desentralisasi dalam suatu organisasi akan memberikan kewenangan dan tanggung jawab yang lebih besar dalam penyusunan anggaran dari pimpinan SKPD kepada bawahannya. Struktur organisasi yang disertai dengan tingkat struktur sentralisasi yang tinggi, menunjukkan bahwa semua keputusan yang penting akan ditentukan pimpinan (manajemen) puncak, sementara manajemen pada tingkat menengah atau bawahannya hanya mempunyai sedikit wewenang didalam pembuatan keputusan. Sedangkan struktur desentralisasi yang tinggi maka akan memberikan gambaran yang sebaliknya, yaitu pimpinan puncak mendelegasikan wewenang dan pertanggungjawaban pada bawahannya, dan bawahan tersebut diberi kekuasaan atau wewenang untuk membuat berbagai macam keputusan (Riyadi, 1998).

Strategi desentralisasi adalah suatu alat dalam pengendalian manajemen yang paling sering digunakan untuk memotivasi dan membantu. Desentralisasi di sektor pemerintahan terjadi dari kepala daerah satuan kerja perangkat daerah (SKPD), satuan kerja pengelola keuangan daerah (SKPKD) dan sekretaris daerah. Desentralisasi dalam hal ini adalah penyerahan wewenang dari pemerintah pusat kepada pemerintah daerah untuk mengurus urusan yang ada di daerah tersebut. Masing-masing SKPD menyusun format Rencana Kerja dan Anggaran (RKA) SKPD.

Penelitian Locke (1967), Kenis (1979), Darma (2004), Abdullah (2004) menunjukkan bahwa kejelasan sasaran anggaran mempengaruhi kinerja manajerial dan akuntabilitas kinerja instansi pemerintah secara positif. Namun sebaliknya, penelitian Jumirin (2001) dan Adoe (2002), menyatakan bahwa kejelasan sasaran anggaran tidak berpengaruh terhadap kinerja manajerial. Syafrial (2009) dalam penelitiannya menyimpulkan bahwa terdapat hubungan yang tidak signifikan antara ketepatan skedul penyusunan anggaran dengan kinerja manajerial. Sedangkan penelitian mengenai hubungan kejelasan sasaran anggaran dengan kinerja manajerial belum didapatkan hasil yang konsisten. Kenis (1979), Abdullah (2004), Kusumaningrum (2010) dan Zainura (2010) mengatakan terdapat hubungan yang signifikan antara kejelasan tujuan anggaran dengan kinerja instansi pemerintah. Sebaliknya penelitian Adoe (2002) dan Bangun (2009) mengatakan tidak terdapat hubungan yang signifikan antara kejelasan tujuan anggaran dengan kinerja instansi pemerintah. Sedangkan penelitian mengenai hubungan struktur desentralisasi dengan kinerja manajerial, Syafruddin (2005), Bangun (2009) mengatakan terdapat hubungan yang signifikan antara struktur desentralisasi dengan kinerja manajerial SKPD.

Penelitian ini mencoba
mereplikasi beberapa penelitian
sebelumnya dengan mengambil lokasi di
Kota Magelang. Kota Magelang ini juga
tidak terlepas dari permasalahan kinerja
beberapa SKPD yang belum
menunjukkan hasil yang maksimal.

\section{LANDASAN TEORI DAN PENGEMBANGAN HIPOTESIS Partisipasi penyusunan anggaran dan kinerja manajerial SKPD}

Partisipasi dalam penyusunan anggaran dapat diartikan merupakan keikutsertaan seseorang dalam menyusun dan memutuskan anggaran secara bersama. Sukses atau gagalnya para staf dalam suatu SKPD dalam melaksanakan anggaran adalah merupakan suatu refleksi langsung tentang keberhasilan ataupun kegagalan manajerial SKPD dalam melaksanakan tugas dan tanggungjawab yang diembannya. Disamping itu tingkat partisipasi para staf dalam penyusunan anggaran akan mendorong moral kerja yang tinggi dan inisiatif serta kegairahan manajerial SKPD. Dalam organisasi sektor publik, partisipasi anggaran dan 
pengukuran kinerja tidak sebatas pada masalah pemakaian anggaran, namun pengukuran kinerja mencakup berbagai aspek yang dapat memberikan informasi yang efisien dan efektif dalam mencapai hasil yang diinginkan kinerja. Aspek-aspek yang dapat memberikan informasi yang efektif dan efisien seperti masukan, kualitas, keluaran, hasil, efisiensi. Dalam hal ini penyusunan anggaran digunakan dalam pendekatan kinerja, maka setiap alokasi biaya yang direncanakan harus dikaitkan dengan tingkat pelayanan atau hasil yang diharapkan tercapai. Kinerja pemerintah daerah dapat diukur melalui evaluasi terhadap pelaksanaan anggaran (Kepmendagri No. 13 tahun 2006).

Anggaran yang telah disusun memiliki peranan sebagai perencanaan dan sebagai kriteria kinerja, yaitu anggaran dipakai sebagai suatu sistem pengendalian untuk mengukur kinerja aparat pemerintah daerah. Untuk mencegah dampak fungsional atau disfungsional, sikap dan perilaku anggota organisasi dalam penyusunan anggaran perlu melibatkan bawahan (aparat pemerintah daerah). Sehingga partisipasi anggaran dapat dinilai sebagai pendekatan aparat pemerintah daerah yang dapat meningkatkan kinerja setiap anggota organisasi sebagai individual karena dengan adanya partisipasi dalam penyusunan anggaran diharapkan setiap aparat pemerintah daerah mampu meningkatkan kinerjanya sesuai dengan target yang telah ditetapkan sebelumnya.

Penelitian Suhartono, Halim (2005) bahwa partisipasi penyusunan anggaran berpengaruh positif signifikan terhadap kinerja manajerial SKPD di Pemerintahan daerah. Sejalan dengan pernyataan Riyadi (1998) bahwa partisipasi penyusunan anggaran merupakan sarana bagi karyawan untuk dapat lebih mengerti terhadap apa yang mereka kerjakan. Selanjutnya, partisipasi penyusunan anggaran akan membantu karyawan untuk memperbaiki kinerja mereka dengan mengetahui target anggaran. Demikian juga penelitian Argrys
(1952) dalam Kenis (1979) yang mengatakan kunci dari kinerja yang efektif adalah partisipasi dari bawahan memegang peranan penting dalam pencapaian tujuan tersebut. Penelitian sebelumnya tentang partisipasi penyusunan anggaran dengan kinerja manajerial, seperti Brownel (1984), Brownell dan McClunes (1986), Frucat dan Shearon (1991), Indriantoro (2000), Lusyanda (2001), Adoc (2002), Syafrudin (2005) serta Bangun (2009).

Hipotesis yang diajukan adalah:

H1. Partisipasi dalam penyusunan

anggaran berpengaruh terhadap

peningkatan kinerja manajerial SKPD.

\section{Kejelasan sasaran anggaran dan kinerja manajerial SKPD}

Sistem pengukuran kinerja yang dapat mengindikasikan orientasi pemenuhan kepuasan/kebutuhan masyarakat adalah penetapan indikator dan target kinerja yang jelas dan terukur. Penetapan indikator dan target kinerja merupakan tahap penting yang harus dilakukan secara hati-hati. Penetapan indikator dan target kinerja penting untuk menentukan keberhasilan SKPD dalam melaksanakan program dan kegiatan. Penetapan kinerja diharapkan tidak menimbulkan kesenjangan penilaian antara masyarakat dan pemerintah daerah.

Locke (1968) dalam Kenis (1979) mengatakan kejelasan sasaran anggaran disengaja untuk mengatur perilaku karyawan. Ketidakjelasan sasaran anggaran akan menyebabkan pelaksana anggaran menjadi bingung, tidak tenang dan tiak puas dalam bekerja. Hal ini menyebabkan pelaksanaan anggaran tidak termotivasi untuk mencapai kinerja yang diharapkan. Penetapan tujuan spesifik akan lebih produktif daripada tidak menetapkan tujuan spesifik. Hal ini akan mendorong karyawan untuk melakukan yang terbaik bagi pencapaian tujuan yang dikehendaki sehingga dapat berimplikasi pada peningkatan kinerja.

Kenis (1979), bahwa kejelasan sasaran anggaran merupakan sejauh mana 
tujuan anggaran ditetapkan secara jelas dan spesifik dengan tujuan agar anggaran tersebut dapat dimengerti oleh orang yang bertanggungjawab atas pencapaian sasaran tersebut. Oleh sebab itu sasaran anggaran daerah harus dinyatakan secara jelas, spesifik dapat dimengerti oleh mereka ynang bertanggungjawab untuk melaksanakannya.

Penelitian Suharto, Halim (2005) menyimpulkan kejelasan sasaran anggaran berpengaruh positip signifikan terhadap kinerja manajerial Pemda. Penelitian Syafrial (2009), menyimpulkan bahwa kejelasan sasaran anggaran berpengaruh secara signifikan terhadap kinerja manajerial SKPD. Penelitian Bangun (2009) kejelasan sasaran anggaran tidak berpengaruh terhadap kinerja SKPD. Maka perumusan Hipotesisnya adalah:

H2. Kejelasan sasaran anggaran berpengaruh terhadap peningkatan kinerja manajerial SKPD.

\section{Struktur desentralisasi dan kinerja manajerial SKPD}

Strategi desentralisasi adalah salah satu alat dalam manajemen pengendalian kebanyakan yang digunakan untuk memotivasi dan membantu manajer di dalam memenuhi kinerjanya (Subrammanyan dan Mia, 2001). Di dalam organisasi publik desentralisasi akan menunjukan tingkat otonomi yang didelegasikan pada manajerial SKPD sehingga manajerial SKPD mempunyai tanggung jawab yang lebih besar terhadap perencanaan dan pengendalian aktivitas operasi serta membutuhkan informasi yang lebih banyak. Jadi organisasi yang strukturnya lebih terdesentralisasi seperti pelaksanaan otonomi daerah di Indonesia, para manajerial SKPD mempunyai otonomi yang lebih besar dalam proses pengambilan atau penetapan keputusan.

Otonomi pengambilan keputusan ini antara lain meliputi tanggungjawab pimpinan kepala dinas atau badan secara keseluruhan terhadap unit kerja yang dipimpinnya. Semakin struktur terdesentralisasi organisasi di pemerintahan daerah, maka semakin tinggi pula kinerja kepala SKPD dalam menjalankan pengelolaan keuangan daerah.

Penelitian Bangun (2009) bahwa struktur desentralisasi mempunyai pengaruh yang signifikan terhadap kinerja manjerial SKPD. Nugraeni dan Budiantara (2013) bahwa struktur desentralisasi berpengaruh terhadap peningkatan kinerja manajerial aparat pemerintah. Hipotesis yang diajukan adalah:

H3. Struktur Desentralisasi berpengaruh terhadap peningkatan kinerja manajerial SKPD.

\section{METODA PENELITIAN \\ Pengumpulan data dan pengambilan sampel}

Populasi dalam penelitian ini adalah pada 26 SKPD di Kota Magelang. Sampel penelitian ini pegawai yang berkaitan dengan akuntansi dan penyusunan anggaran. Data dikumpulkan dengan cara peneliti mengirim kuisioner. Dari kuisioner yang dikirim, hanya 75 kuisioner yang memenuhi syarat untuk diproses.

\section{Definisi Operasional variabel}

Kinerja manajerial SKPD (Y) adalah sebagai hasil dari proses aktivitas manajerial yang efektif mulai dari proses perencanaan dan penganggaran, penatausahaan, pelaporan, pertanggungjawaban dan pengawasan. Variabel kinerja manajerial ini diukur dengan menggunakan skala 5 point yang diadaptasi dari penelitian Bangun (2009) dengan mempertimbangkan pelaksanaan tugas-tugas manajerial SKPD dalam pengelolaan keuangan yang terdapat di Pemerintah daerah.

Partisipasi dalam penyusunan anggaran $\left(\mathrm{X}_{1}\right)$ adalah partisipasi manajerial SKPD dalam proses penganggaran daerah, seperti program dam kegiatan yang akan dilaksanakan, keikutsertaan dalam menentukan target dan anggaran dan 
sebagainya. Variabel partisipasi dalam penyusunan anggaran ini diukur dengan menggunakan skala 5 point yang diadaptasi dari penelitian Bangun (2009) dengan mempertimbangkan pelaksanaan tugas-tugas manajerial SKPD dalam pengelolaan keuangan yang terdapat di Pemerintah daerah.

Kejelasan sasaran anggaran $\left(\mathrm{X}_{2}\right)$ merupakan rencana kerja keuangan yang dituangkan dalam bentuk anggaran disusun secara jelas dan spesifik sehingga dapat dimengerti oleh orang yang bertanggung jawab agar dapat mencapai tujuan secara efisien, efektif dan ekonomis. Untuk mengukur variabel kejelasan sasaran anggaran ini digunakan skala 5 poin. Kuisioner ini melihat rencana keuangan yang jelas dan spesifik yang akan dicapai oleh SKPD, kuisioner ini didesain dengan mengadaptasi dari penelitian Bangun (2009).

Struktur desentralisasi (X3) adalah proses penentuan kegiatan, penentuan nilai, penentuan orang yang bertanggung jawab atas program dan kegiatan, menentukan prioritas program dan kegiatan. Variabel struktur desentralisasi diukur dengan skala 5 poin untuk menunjukkan derajat otoritas yang didelegasikan orang-orang yang terlibat langsung dalam penyiapan dan proses penyusunan APBD, kuisioner ini didesain dengan mengadaptasi dari penelitian Bangun (2009).

\section{Teknik analisis data}

Hipotesis dalam penelitian ini diuji menggunakan analisis regresi berganda (multiple regression) dengan persamaan: Ykin $=\mathrm{b} 0+\mathrm{b}_{1} \mathrm{X}_{1}+\mathrm{b}_{2} \mathrm{X}_{2}+\mathrm{b}_{3} \mathrm{X}_{3}+\mathrm{e}$

\section{Dimana:}

$\begin{array}{ll}\text { Ykin } & =\text { kinerja manajerial SKPD } \\ \mathrm{b} 0 & =\text { konstanta } \\ \mathrm{b}_{1}, \mathrm{~b}_{2}, \mathrm{~b}_{3}, & =\text { koefisien regresi } \\ \mathrm{X}_{1} & =\text { partisipasi penyusunan } \\ \text { anggaran } & \\ \mathrm{X}_{2} & =\text { kejelasan sasaran } \\ \text { anggaran } & \\ \mathrm{X}_{3} & =\text { struktur desentralaisasi }\end{array}$

\section{HASIL DAN PEMBAHASAN}

Hipotesis 1 adalah pengujian untuk melihat pengaruh Partisipasi dalam penyusunan anggaran terhadap peningkatan kinerja manajerial SKPD. Dari tabel dibawah ini terlihat bahwa $\mathrm{t}$ hitung $(2,985)>t$ tabel $(1,994)$, hal ini menandakan bahwa hipotesis 1 yang menyatakan bahwa Partisipasi dalam penyusunan anggaran berpengaruh terhadap peningkatan kinerja manajerial SKPD dapat diterima. Partisipasi penyusunan anggaran sangat erat hubungannya dengan kinerja aparat pemerintah daerah, karena kinerja aparat pemerintah dilihat berdasarkan partisipasi aparat pemerintah dalam menyusun anggaran. Tingkat partisipasi para staf dalam penyusunan anggaran akan mendorong moral kerja yang tinggi dan inisiatif serta kegairahan manajerial SKPD. Melibatkan para manajerial SKPD dalam sistem perencanaan berarti menghargai kebutuhan untuk sebuah lingkungan kerja yang nyaman dan ramah, yang mendukung terlaksananya komunikasi yang baik, karena gagasan mereka akan dihargai dan diterapkan merupakan kepuasan tersendiri. Begitu pula halnya dalam proses penyusunan anggaran, apabila para manajerial SKPD ikut berpartisipasi untuk merumuskannya, maka besar kemungkinan hasil yang akan diperoleh dari realisasi anggaran jauh lebih baik karena adanya tanggung jawab moril. Bagaimanapun anggaran hanya efektif jika mendapat dukungan dari semua pihak, dan untuk mengusahakan supaya anggaran ini mendapat dukungan dari bawahan maka dapat ditempuh melalui cara penyusunan secara demokratis atau bottom up. Kunci dari kinerja yang efektif adalah partisipasi dari bawahan memegang peranan penting dalam pencapaian tujuan tersebut. Hal ini sejalan dengan penelitian Suhartono, Halim (2005), Riyadi (1998), Argrys (1952) dalam Kenis (1979), Brownel (1984), Brownell dan McClunes (1986), Frucat dan Shearon (1991), Indriantoro 
(2000), Lusyanda (2001), Adoc (2002), Syafrudin (2005) serta Bangun (2009)

Hipotesis 2 adalah pengujian untuk melihat pengaruh Kejelasan sasaran anggaran terhadap peningkatan kinerja manajerial SKPD. Dari tabel 1. dibawah ini terlihat bahwa t hitung $(3,329)>t$ tabel $(1,994)$, hal ini menandakan bahwa hipotesis 2 yang menyatakan bahwa Kejelasan sasaran anggaran berpengaruh terhadap peningkatan kinerja manajerial SKPD dapat diterima. Kejelasan sasaran anggaran disengaja untuk mengatur perilaku pegawai. Ketidakjelasan sasaran anggaran akan menyebabkan pelaksanaan anggaran menjadi bingung, dan tidak puas dalam bekerja. Hal ini menyebabkan pelaksana anggaran tidak termotivasi untuk mencapai kinerja yang diharapkan. Kejelasan sasaran anggaran akan membantu pegawai untuk mencapai kinerja yang diharapkan, dimana dengan mengetahui sasaran anggaran tingkat kinerja dapat tercapai. Pencapaian kinerja ini akan terkait dengan motivasi, dimana hal ini disebabkan dengan motivasi yang tinggi akan membantu pegawai untuk mencapai kinerja yang diharapkan. Dengan kata lain, kinerja manajerial akan dipengaruhi oleh kejelasan sasaran anggaran Hal ini sejalan dengan penelitian Suharto, Halim (2005), Syafrial (2009) dan Bangun (2009).
Hipotesis 3 adalah pengujian untuk melihat pengaruh Struktur Desentralisasi terhadap peningkatan kinerja manajerial SKPD. Dari tabel 1, dibawah ini terlihat bahwa $\mathrm{t}$ hitung $(3,321)>\mathrm{t}$ tabel $(1,994)$, hal ini menandakan bahwa hipotesis 3 yang menyatakan bahwa Struktur Desentralisasi berpengaruh terhadap peningkatan kinerja manajerial SKPD dapat diterima. Tingkat atau intensitas partisipasi anggaran dan derajat struktur organisasi yang terdesentralisasi akan meningkatkan kinerja orang yang terlibat dalam partisipasi dan struktur tersebut. Organisasi yang strukturnya lebih terdesentralisasi seperti pelaksanaan otonomi daerah di Indonesia, para manajerial SKPD mempunyai otonomi yang lebih besar dalam proses pengambilan atau penetapan keputusan. Dengan otonomi yang semakin tinggi ini, dapat diprediksikan bahwa Kepala Badan dan Kepala Dinas akan lebih bertanggungjawab, selanjutnya kinerja manajerial juga menjadi semakin meningkat. Dengan kata lain, semakin struktur terdesentralisasi organisasi di pemerintahan daerah, maka semakin tinggi pula kinerja kepala SKPD dalam menjalankan pengelolaan keuangan daerah. Hal ini sejalan dengan penelitian Bangun (2009), Nugraeni dan Budiantara (2013).

Tabel 1.

Coefficients $^{\text {a }}$

\begin{tabular}{|c|c|c|c|c|c|c|c|c|}
\hline \multirow{2}{*}{\multicolumn{2}{|c|}{ Model }} & \multicolumn{2}{|c|}{$\begin{array}{l}\text { Unstandardized } \\
\text { Coefficients }\end{array}$} & \multirow{2}{*}{$\begin{array}{c}\text { Standardize } \\
\mathrm{d} \\
\text { Coefficient } \\
\mathrm{s}\end{array}$} & \multirow[b]{2}{*}{$\mathrm{t}$} & \multirow[b]{2}{*}{ Sig. } & \multicolumn{2}{|c|}{$\begin{array}{c}\text { Collinearity } \\
\text { Statistics }\end{array}$} \\
\hline & & B & Std. Error & & & & $\begin{array}{c}\text { Toleran } \\
\text { ce }\end{array}$ & VIF \\
\hline \multirow[t]{4}{*}{1} & (Constant) & ,652 &, 442 & & 1,477 &, 144 & & \\
\hline & $\begin{array}{l}\text { partisipasi } \\
\text { anggaran }\end{array}$ & ,394 & ,132 & ,351 & 2,985 & ,004 & ,526 & 1,902 \\
\hline & $\begin{array}{l}\text { kejelasan } \\
\text { anggaran }\end{array}$ & ,390 & , 117 & ,391 & 3,329 & ,001 & ,526 & 1,901 \\
\hline & $\begin{array}{l}\text { struktur } \\
\text { desentralisasi }\end{array}$ & ,360 & ,116 & ,379 & 3,321 & ,036 & ,986 & 1,015 \\
\hline
\end{tabular}




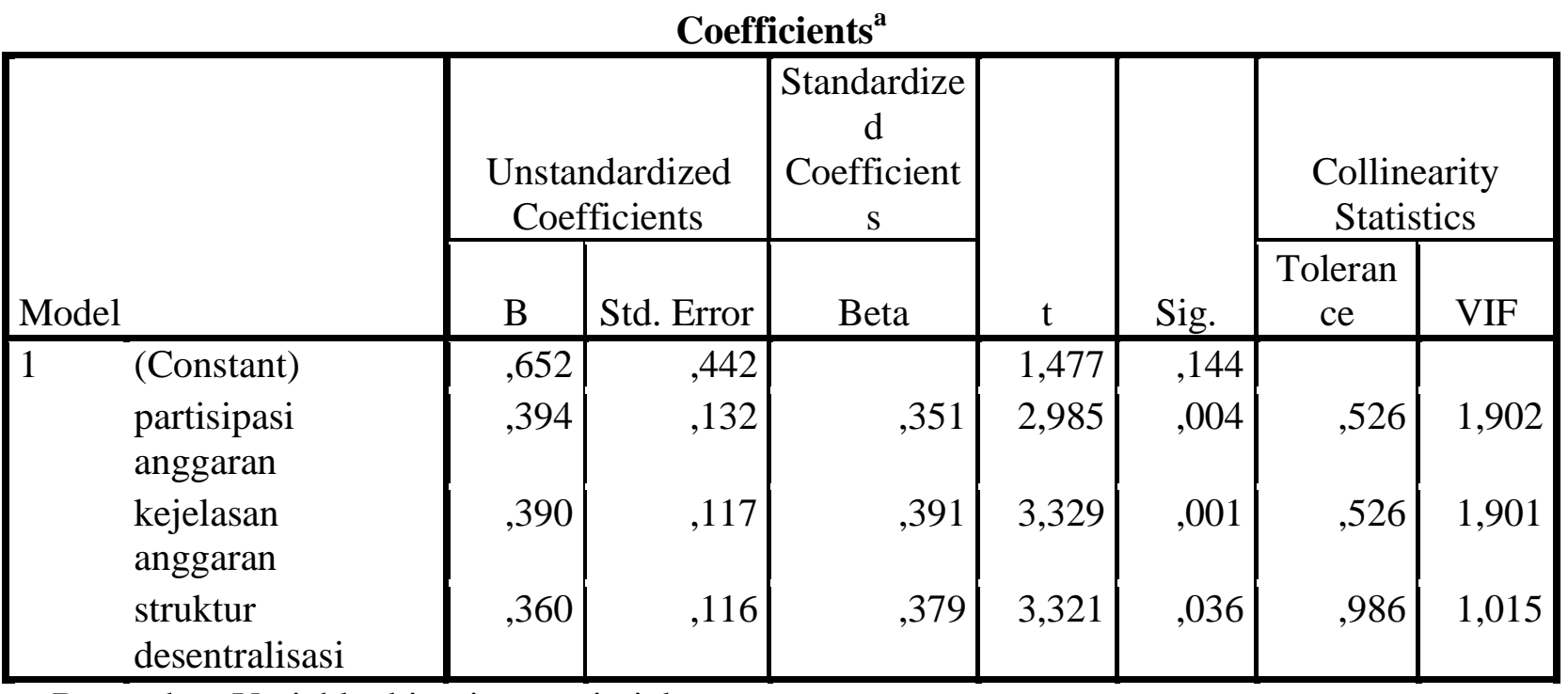

a. Dependent Variable: kinerja manajerial sumber: output SPSS

Sedang pengaruh ketiga variabel yaitu Partisipasi dalam penyusunan anggaran, Kejelasan sasaran anggaran dan Struktur Desentralisasi secara bersama-sama terhadap peningkatan kinerja manajerial SKPD dapat ditunjukan dalam tabel 2 dibawah ini. Dari tabel 2 dapat dilihat bahwa nilai $\mathrm{F}$ hitung $(22,211)>\mathrm{F}$ tabel (1,41). Hal ini menunjukan bahwa ketiga variabel (Partisipasi dalam penyusunan anggaran, Kejelasan sasaran anggaran dan Struktur Desentralisasi) secara bersamasama berpengaruh terhadap peningkatan kinerja manajerial SKPD

Tabel 2.

ANOVA $^{b}$

\begin{tabular}{|ll|r|r|r|r|r|}
\hline \multicolumn{2}{|l|}{ Model } & \multicolumn{1}{|c|}{$\begin{array}{c}\text { Sum of } \\
\text { Squares }\end{array}$} & df & \multicolumn{1}{c|}{$\begin{array}{c}\text { Mean } \\
\text { Square }\end{array}$} & F & Sig. \\
\hline 1 & Regression & 11,834 & 3 & 3,945 & 22,211 &, $000^{\mathrm{a}}$ \\
& Residual & 12,610 & 71 &, 178 & & \\
& Total & 24,443 & 74 & & & \\
\hline
\end{tabular}

a. Predictors: (Constant), struktur desentralisasi, kejelasan anggaran, partisipasi anggaran

b. Dependent Variable: kinerja manajerial sumber: output SPSS

\begin{abstract}
KESIMPULAN
KETERBATASAN

Kesimpulan

Adapun kesimpulan dari penelitian ini adalah bahwa Partisipasi dalam penyusunan anggaran, Kejelasan sasaran anggaran dan Struktur Desentralisasi berpengaruh terhadap peningkatan kinerja manajerial SKPD baik secara parsial maupun simultan.

DAN
\end{abstract}

\section{Keterbatasan}

1. Tidak dilakukannya metode wawancara dalam penelitian, mengingat kesibukan dari pihak dinas sendiri, dan responden meminta agar kuesioner ditinggalkan, sehingga peneliti tidak bisa mengendalikan jawaban responden.

2. Ruang lingkup dalam penelitian ini sangat kecil. Sampel yang digunakan dalam penelitian ini berasal dari dinas, badan dan kantor yang berasal dari pemerintah Kota 
Magelang saja, yang mungkin saja hasilnya berbeda jika menggunakan sampel dan ruang lingkup yang lebih luas, misalnya pada pemerintah kabupaten dan kota se-provinsi.

\section{DAFTAR PUSTAKA}

Abdullah, 2004,"Pengaruh kejelasan sasaran anggaran, pengendalian akuntansi dan sistem pelaporan terhadap akuntabilitas kinerja instansi pemerintah pada kabupaten dan kota di Daerah Istimewa Yogyakarta", Tesis, Program Pasca Sarjana UGM, Yogyakarta.

Adoc, M, H, 2002, "Pengaruh karakteristik tujuan anggaran terhadap perilaku, sikap dan kinerja pemerintah daerah dipropinsi Nusa Tenggara Timur", Tesis, Program Pasca Sarjana UGM, Yogyakarta.

Anthony, RN and Govindrajan, V, 1998, "Manajemen Control System", Richard D. Irwin Inc.

Bangun, Andarias. (2009). "Pengaruh Partisipasi dalam Penyusunan Anggaran, Kejelasan Sasaran Anggaran dan Struktur Desentralisasi terhadap Kinerja Manajerial SKPD dengan Pengawasan Internal sebagai Variabel Pemoderasi (Studi Kasus pada Pemerintah Kabupaten Deli Serdang". Tesis, Universitas Sumatera Utara, Medan.

Bastian, I, 2001, "Akuntansi Sektor Publik di Indonesia", Pusat Pengembangan Akuntansi, Yogyakarta, BPFE.

Burn, W.J and Waterhouse, 1975,"Budgetary Control and Organization Structure", Journal of Accounting Research, Autumn, pp. 177-203.
Chia, Y.M. 1995, "Decentralization, Management Accounting system Information Characteristic and Their Interaction Effects on Managerial Performance: A Singapore study", Journal of Business, Finance and Accounting, pp. 811-830.

Duwi Priyatno, 2009,"Belajar Olah data dengan SPSS 17", Penerbit Andi Yogyakarta

Frucot, V and Shearon, W.T, 1991, "Budgetary Participation, Locus of Control and Mexican Managerial Performance and Job Satisfaction", The Accounting Review, Vol. 66, No. 1, January, pp. 80-99

Govindrajan, V, 1986, "Decentralization, Strategy, and Effectiveness of strategic Business Units in MultiBusiness Organization", Academy of Management, Review 11, pp. 844-856.

Hill, F.A and G. Yukl, 1969,"Corporate Control Type, Strategy, Size and Financial Performance", Journal of management studies, pp. 125-136

Indrantoro, N, 1993, "The Effect of Participative Budgeting on Job Performance and Job Satisfaction with Locus of Control and Cultural dimentions as Moderating Variables", University of Kentucky, Dissertation.

Indraswari Kusumaningrum, 2010, "Pengaruh Kejelasan Sasaran Anggaran, Pengendalian Akuntansi dan Sistem Pelaporan Terhadap Akuntabilitas Kinerja Instansi Peme

Tesis S-2 Universitas Diponegoro Semarang 
Kenis, 1979,"Effect on Budgetary good characteristic on Managerial Attitude anda Performance", The Accounting Review.

LAN dan BPKP, 2000, "Modul Sosialisasi Sistem Akuntabilitas Kinerja Instansi Pemerintah", Lembaga Akuntansi Negara.

Mardiasmo, 2002,"Akuntansi Sektor Publik", Yogyakarta Penerbit Andi

Miah, N.Z and Mia. L, 1996, "Decentralization, Accounting Control System and Performance of Government Organization; A New Zealand Empirical study", financial Accountability and Management, August, Vol. 12, No. 3, pp, 173189

Nugraeni, Budiantara, 2013, "Efek Desentralisasi dan Sistem Pengendalian Akuntansi ke Arah Kinerja Manajer Kantor Dengan Locus of Control Sebagai Variabel Moderating; studi pada kantor dinas pendidikan pemuda dan olahraga Kabupaten Sleman", Jurnal Bisnis dan Ekonomi, UMM, Volume 2

Permendagri No. 13 tahun 2006 tentang Pedoman Pengelolaan Keuangan Daerah.

Riyadi, S. (1998). "Motivasi dan Pelimpahan Wewenang sebagai Variabel Moderating dalam Hubungan Antara Partisipasi Penyusunan Anggaran dan Kinerja Manajerial". Tesis, UGM, Yoagyakarta.

Riyanto, B, 1997,"The Effect of Attitude, Strategy and Decentralization on The Effectiveness of Budget
Participation" Journal Riset akuntansi Indonesia, Vol.2, No. 2 July, pp, 136-153

Syafrial. (2009). "Pengaruh Ketepatan Skedul Penyusunan Anggaran, Kejelasan Sasaran Anggaran dan Partisipasi Penyusunan Anggaran Terhadap Kinerja Manajerial SKPD pada Pemerintah Kabupaten Sarolangun". Tesis, Universitas Sumatera Utara, Medan.

Syafruddin, Muhammad. (2005). "Pengaruh Moderasi Faktor Inovasi pada Hubungan Partisipasi Anggaran, Struktur Terdesentralisasi dan Kinerja Manajemen (Studi di Organisasi Pemerintah Daerah)". Jurnal Akuntansi dan Keuangan Sektor Publik. Vol.06 No.02. Agustus 2005. Yogyakarta. Hal 73-104.

Subrammanian, N and Mia L, 2001, "The Relation between Decentralized structure, Budgetary Participation and Organizational Commitment, The Moderating Role of Manager's Value Orientation toward Innovation", Accounting Auditing \& Accountability, Journal, vol.14, No. 1, pp, 12-29

UU No. 32 Tahun 2004 : Pemerintahan Daerah

UU No. 33 Tahun 2004 : Perimbangan Keuangan antara Pemerintah Pusat dan tahan Daerah

Zainura. (2010). "Pengaruh Penerapan Anggaran Berbasis Kinerja dan Kejelasan Sasaran Anggaran terhadap Kinerja Keuangan Pemerintah Daerah (Studi di SKPD pada Pemerintah Kotamadya Banda Ac Tesis, Universitas Syiah Kuala, Banda Aceh 